\title{
Effect of Feeding on Juvenile Growth Rate of Wader Fish (Rashbora argyrotaenia)
}

\author{
Ravita Kusuma Dewi ${ }^{1}$, I Wayan Arthana ${ }^{1}$, and Dewa Ayu Angga Pebriani ${ }^{1}$ \\ ${ }^{1}$ Department of Aquatic Resources Management, Faculty of Marine and Fisheries, Udayana University \\ Jl. Kampus Unud Bukit Jimbaran, Kuta Selatan, Badung, Bali \\ *Corresponding author: ravitakusumadewi1830@gmail.com
}

\begin{abstract}
Aquaculture is an activity to develop, acquire, reproduce and produce fisheries with the help of human resources. One method of cultivation is wader fish (Rashbora argyrotaenia) which is known for its very slow growth and relatively small size. This study aims to determine the growth rate of wader fish with different feeds in Blado Kulon Village, Tegalsiwalan, Probolinggo. The method used in this study was a completely randomized design with 3 treatments and 3 repetitions. The treatments used were treatment A in the form of fish pellets as control, treatment B consisted of a mixture of snail flour, soybean flour, bran, and tapioca flour, while treatment $\mathrm{C}$ consisted of a mixture of conch flour, cassava leaf flour, bran and tapioca flour. The study was conducted for 42 days. The parameters measured in this study were temperature, $\mathrm{DO}$, and $\mathrm{pH}$, as well as observing the growth of absolute weight, specific growth rate (SGR), survival rate, and feed concentration ratio (FCR). Observations were analyzed using One Way Analysis of Variance (ANOVA) and further tests were performed using the Duncan test. The results showed that different feeding had no significant effect on growth rate, absolute weight, feed conversion ratio and survival of wader fish. Water quality parameters measured include an average temperature of $28.42^{\circ} \mathrm{C}-$ $28.54{ }^{\circ} \mathrm{C}$, while the average $\mathrm{pH}$ is $7.42-7.50$, and dissolved oxygen (DO) with an average of $5.54-6.23 \mathrm{mg} / \mathrm{L}$.
\end{abstract}

Keywords: Wader Fish; Growth Rate; Alternative Feed

\section{INTRODUCTION}

Aquaculture is an activity to develop and get results from a system used to reproduce or produce in the field of fisheries with the help of human resources [1]. One of the aquaculture commodity is wader fish (Rashbora argyrotaenia). Wader fish is a very slow growing fish with a relatively small size and takes a long time to grow. Feed is a source of energy used to support fish life and growth, which is also the largest component of production costs, reaching 50-70\% [2]. According to Yanuar [3], the speed of fish growth is very much influenced by the type and quality of feed given and environmental conditions.

In general, the feed used by fish cultivators is pellets which can significantly stimulate fish growth [4]. However, until now, pellet feed on the market has a relatively expensive price. This causes farmers to experience problems in spurring fish growth and causes the selling price of fish to become unstable so that innovations have emerged to create alternative feed from local raw materials. Local raw materials are materials used in the surrounding environment, easy to obtain and relatively cheap if used as an alternative feed for fish feed. Local raw materials used for alternative fish feed are soybean dregs, bran, conch flour and cassava leaf flour. This research was conducted as an effort to determine the effect of alternative feeds from different feeding resources on the growth rate of juvenile wader fish.

\section{METHODS}

The experimental design used a completely randomized design consisting of three treatments and three replications. The test material used was wader fish (Rashbora argyrotaenia). The seeds used were $1-2 \mathrm{~cm}$ in length size, $100 \mathrm{ind} . / \mathrm{m}^{2}$. The treatments performed were treatment A (fed by pellets), treatment B (fed by a mixture of soybean dregs, snail flour, bran and tapioca flour), treatment $\mathrm{C}$ (fed by a mixture of cassava leaf flour, conch flour, bran and tapioca flour).

\section{Location and Research period}

The research was conducted in Blado Kulon Village, Tegalsiwalan District, Probolinggo Regency, East Java. Data collection was carried out for 42 days from 30 November 2020 - 10 January 2021 with sample measurements was conducted once a week.

\section{Tools and Materials}

The tools used in this study were $\mathrm{pH}$ pen, DO meter, digital scale, bucket, hose, camera, notebook, filter, pipe, basin, ruler, net, while the materials used in this study were seeds 1-2 cm in size. commercial feed, bran, soybean dregs, cassava leaf flour, tapioca flour, and water. 


\section{Research Parameters}

The parameters measured were absolute weight growth, specific growth rate (SGR), feed conversion ratio (FCR) and survival rate (SR). The supporting parameter in this research is water quality which includes temperature, DO, and $\mathrm{pH}$. The formula used in the study is as follows:

\section{Absolute Weight Growth}

Absolute weight growth is the difference between the average weight of the fish at the end of the rearing minus the average weight of the fish at the beginning of rearing [5].

$$
\mathrm{W}=\mathrm{Wt}-\mathrm{W} 0
$$

Noted : W: Absolute weight growth (g), Wt: the average weight of wader fish at the end of the study (g), W0: mean weight of wader fish at baseline $(\mathrm{g})$

\section{Specific Growth Rate (SGR)}

The specific growth rate is a calculation of the daily growth of wader fish during maintenance that is 42 days. Wader fish juvenile biomass data collection was carried out every 7 days. The specific growth rate is calculated using the formula [6].

$$
\mathrm{SGR}=\mathrm{x} 100 \%
$$

Noted : SGR: Specific Growth Rate (\%), Wt: Weight of fish biomass at the end of the study (g), W0: Weight of biomass at the start of the study $(\mathrm{g}), \mathrm{t}$ : Length of study time (days)

\section{Feed Conversion Ratio (FCR)}

The feed conversion ratio is the ratio between used feed and the weight gain produced at the end of maintenance. According to Djajasewaka [7], the feed conversion ratio can be calculated with the following formula:

$$
\mathrm{FCR}=\frac{F}{(W t+D)-W 0}
$$

Noted : FCR: Feed Conversion Rate, F: Total amount of feed given $(\mathrm{g}), \mathrm{Wt}$ : Weight of feed biomass at the end of the study (g), D: Weight of dead fish (g), W0: Weight of fish biomass at the start of the study $(\mathrm{g})$.

\section{Survival Rate (SR)}

Survival is the ratio of the number of fish that are alive until the end of the study with the number of fish at the start of the study. According to Zairin [8], to calculate survival (SR), the following formula is used:

$$
\mathrm{SR}=\frac{N t}{N 0} \mathrm{x} 100 \%
$$

Noted : SR: Survival (\%), Nt: number of fish at the end of the study (tail), NO: number of fish at the beginning of the study (tail).

\section{Data analysis}

Data analysis used the One Way ANOVA (Analysis of Variance) method with the Statistical Product and Service Solution (SPSS) program, if the different feeds given had a significant or significant effect on the growth rate of wader fish seeds, further tests were carried out using the Duncan test with a significance of $5 \%$.

\section{RESULT AND DISCUSSION}

Proximate Analysis

Three different types of feed were used in this study, namely treatment A were given commercial feed in the form of fish pellets (MS. Preo 891) treatment B was given a mixture of snail flour, soybean dregs, bran, and tapioca flour. While treatment $\mathrm{C}$ was given a mixture of feed from snail flour, cassava leaf flour, bran and tapioca flour. The results of the proximate analysis of feed can be seen in (Table 1). According to Anggitasari [9]. Soy pulp contains $40 \%$ protein, $20 \%$ fat, $35 \%$ carbohydrates. Whereas in feed $\mathrm{C}$ According to Hasim et al., [10] using cassava leaves has a protein content of $6.8 \%, 1.2 \%$ fat, $14 \%$ carbohydrates.

TABLE 1

Proximate Analysis Results

\begin{tabular}{ccccccc}
\hline No & $\begin{array}{c}\text { Sam- } \\
\text { ple }\end{array}$ & Protein & $\begin{array}{c}\text { Carbo- } \\
\text { hydrate }\end{array}$ & fat & $\begin{array}{c}\text { ash } \\
\text { content }\end{array}$ & water \\
\hline 1. & $\begin{array}{c}\text { Treat } \\
\text { ment } \\
\text { A }\end{array}$ & $14,50 \%$ & $25,63 \%$ & $6,05 \%$ & $8,58 \%$ & $10,16 \%$ \\
& $\begin{array}{c}\text { Treat } \\
\text { ment } \\
\text { B }\end{array}$ & $30,11 \%$ & $37,94 \%$ & $7,69 \%$ & $9,38 \%$ & $14,88 \%$ \\
& $\begin{array}{c}\text { Treat } \\
\text { ment } \\
\text { C }\end{array}$ & $28,84 \%$ & $37,28 \%$ & $6,09 \%$ & $11,43 \%$ & $16,36 \%$ \\
\hline
\end{tabular}

Absolute Weight Growth of Wader Fish Seeds (Rashbora argyrotaenia)

Wader fish reared for 42 days using different diets to observe whether the feed had an impact on the growth rate of the absolute weight of wader fish seeds. Based on the results, the absolute weight growth of wader fish seeds has increased every week. The increase in absolute weight growth of wader fish consecutively from the highest to the lowest was treatment $\mathrm{B}$ with an average length of 1.20 grams, treatment $\mathrm{C}$ of 1.00 grams, and treatment $\mathrm{A}$ of 0.83 grams. The results of the One Way ANOVA statistical test showed that all treatments did not have a different effect on the specific growth rate of wader fish. (Figure 2).

According to Marzuqi [11], the growth that occurs every week shows that the feed given can be absorbed and digested to meet the nutritional needs of fish such as protein. According to Nasriani and Irja [12] also stated that protein is the main component to help the growth of the largest fish, namely $65-75 \%$. 


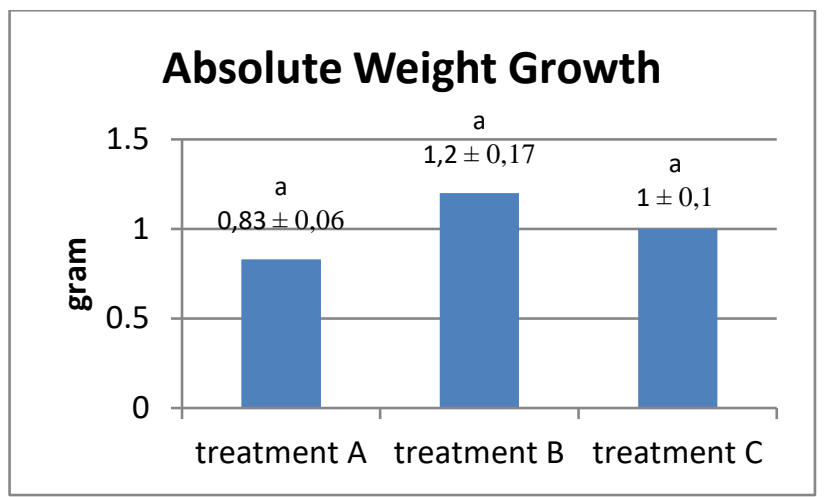

Figure 2. Absolute Weight Growth of Rashbora argrotaenia

Specific Growth Rate (SGR)

Based on the results, the specific growth rate of wader fish seeds has increased every week. The increase in specific growth of wader fish consecutively from the highest to the lowest was treatment $\mathrm{B}$ of $4.58 \%$ per day, treatment $\mathrm{C}$ of $4.47 \%$ per day, and treatment $\mathrm{A}$ of $3.58 \%$ per day. The results of the One Way ANOVA statistical test showed that all treatments did not have a significant effect on the specific growth rate of wader fish. (Figure 3).

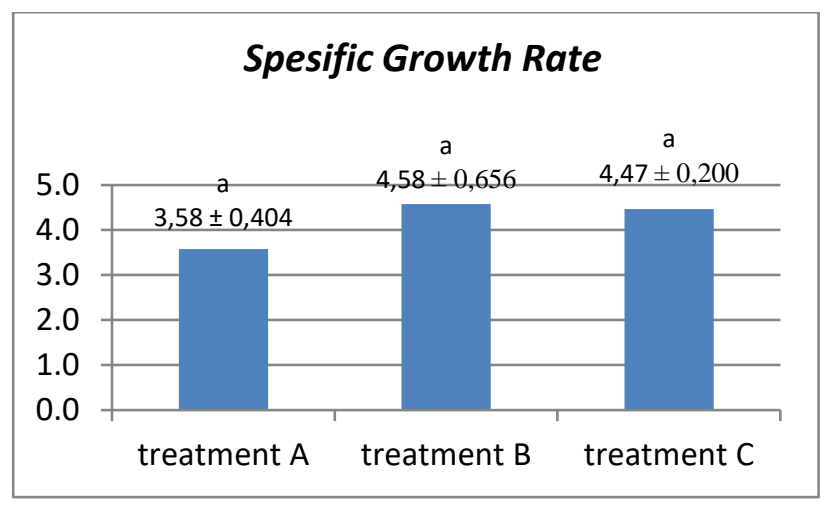

Figure 3. Specific Growth Rate of Rashbora argrotaenia

According to Rachmawati and Samidjan [13] the increase in fish weight is caused by the feed given because feed can be responded to by fish as a process of metabolism and growth. Growth is influenced by the environmental balance of water quality and nutrition contained in the feed. According to Nasrullah [14], a higher water temperature increase can inhibit the growth rate of fish to have an optimal temperature. This is consistent with the statement of Kelabora [15] that changes in temperature can affect the growth and viability of fish fry. This is also supported by Budihardjo's statement [16] which states that a good temperature for freshwater fish farming ranges from $26-30^{\circ}$ C.Feed Conversion Ratio (FCR).

Based on the results of the observations that have been made, it is obtained that the FCR value ranges from 0.95 1.16 with the highest feed conversion rate found in treatment $\mathrm{A}$ which is equal to 1.16 , and treatment $\mathrm{C}$ of 1.03 and treatment $\mathrm{A}$ by 0.95 . The results of the data obtained were then carried out statistical tests using One Way ANOVA and showed that all treatments did not have a significant effect on the wader fish feed conversion ratio. (Figure 4).

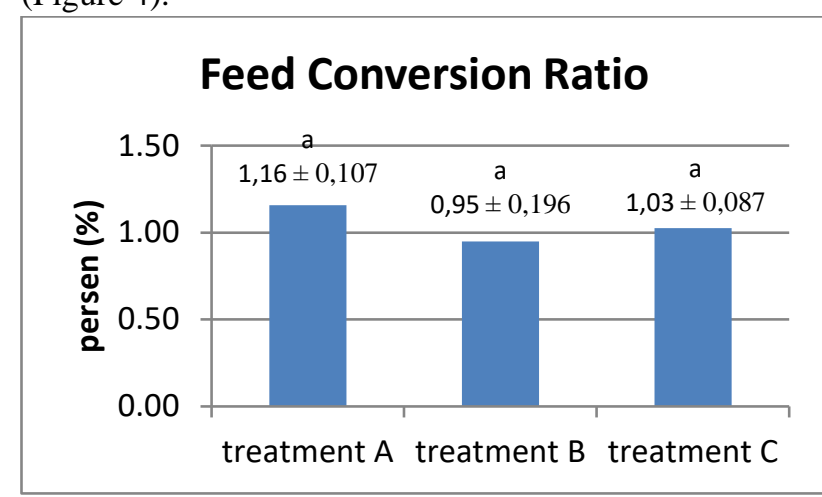

Figure 4. Feed Conversion Ratio of Rashbora argrotaenia

According to Barrows and Hardy [17] the feed ratio conversion value is influenced by several factors such as density, weight of each individual, age of animal groups, water temperature and feeding method (quality, quantity and frequency of feeding). The size of the feed conversion ratio is thought to be due to different nutrient absorption in each species, age, size and number of tested fish. According to Susanti [18] a low feed conversion value means that the quality of the feed given is good. Meanwhile, if the feed conversion value is high it means that the quality of the feed given is not good. The lower the feed ratio value, the better the quality of the feed given.

\section{Survival Rate (SR)}

Based on the results of the observations that have been made, the SR value data obtained ranges from $89 \%-97 \%$. The highest SR value lies in treatment A of $97 \%$, treatment $\mathrm{C}$ of $93 \%$, and treatment $\mathrm{B}$ of $89 \%$. The results were then carried out by One Way ANOVA statistical test which showed that all treatments did not have a significant effect on the survival rate. The results of observations of SR of the wader fish fry can be seen in (Figure 5).

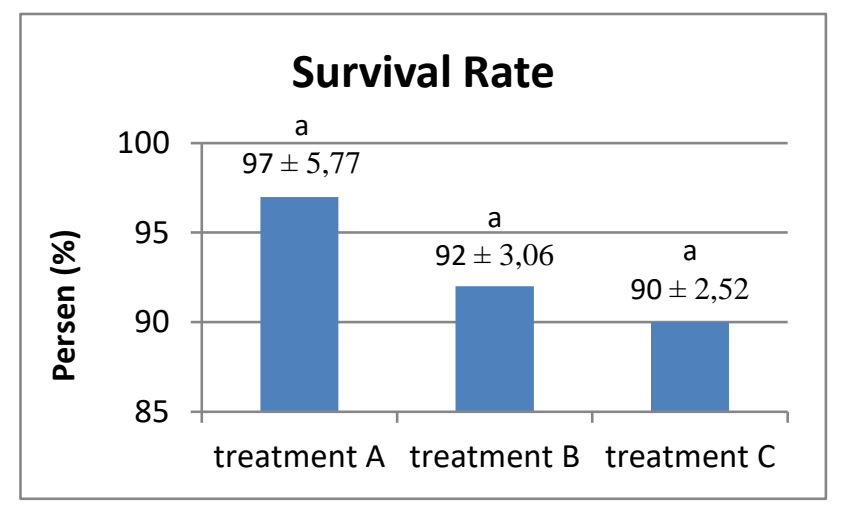

Figure 5. Survival Rate of Rashbora argrotaenia

According to Marzuqi [11] fish that get feed according to their mouth openings will continue their life well and the quality can also affect the level of fish survival in a waters. If the water quality is lacking, it can cause disruption of the physiological conditions of the fish, 
namely a decrease in appetite so that the energy absorbed from the feed is not optimal and the fish die. This agrees with Handajani \& Widodo [19] the survival of fish is influenced by fish species, the environment and the food that is digested and from some of these factors how far it will affect the growth of fish such as water quality factors which include temperature, $\mathrm{pH}$ and $\mathrm{DO}$.

\section{Water Quality}

Based on the results of measurements that have been made during the study, the average temperature value ranges from $28.42^{\circ} \mathrm{C}-28.54^{\circ} \mathrm{C}$. The highest temperature was found in treatment $\mathrm{A}$ at $28.54{ }^{\circ} \mathrm{C}$, treatment $\mathrm{B}$ at 28.47 ${ }^{\circ} \mathrm{C}$, and treatment $\mathrm{C}$ at $28.42{ }^{\circ} \mathrm{C}$. Based on the results of the research that has been done, the average $\mathrm{pH}$ value ranges from 7.37 - 7.50. The highest to lowest $\mathrm{pH}$ values were respectively in treatment $\mathrm{B}$ of 7.50 while treatment $\mathrm{C}$ was 7.47 and treatment $A$ was 7.37. Based on the observations that have been made, it can be seen that the average DO value ranges from $5.54 \mathrm{mg} / \mathrm{L}-6.23 \mathrm{mg} / \mathrm{L}$. The highest to lowest DO value, respectively, lies in treatment $\mathrm{C}$ of $6.23 \mathrm{mg} / \mathrm{L}$, while treatment B is $5.95 \mathrm{mg} / \mathrm{L}$ and treatment $\mathrm{A}$ is $5.54 \mathrm{mg} / \mathrm{L}$ as shown (Table 2).

TABLE 2.

Average Water Quality

\begin{tabular}{lcccc}
\multicolumn{4}{c}{ Average Water Quality } \\
\cline { 2 - 4 } Parameter & \multicolumn{3}{c}{ Treatment } & \\
\cline { 2 - 4 } & $\mathrm{A}$ & $\mathrm{B}$ & $\mathrm{C}$ & \\
\hline $\mathrm{pH}$ & 7,37 & 7,50 & 7,47 & $6.5-8$ \\
$\mathrm{DO}$ & 5,54 & 5,95 & 6,23 & $>3 \mathrm{mg} / \mathrm{l}$ \\
$(\mathrm{mg} / \mathrm{L})$ & 28,54 & 28,42 & 28,47 & $25-30^{\circ} \mathrm{C}$ \\
Suhu $\left({ }^{\circ} \mathrm{C}\right)$ & 28,5 value \\
\hline
\end{tabular}

Temperature is one of the most important parameters of air quality in cultivation activities. Temperature can affect metabolism in the body because if the temperature is relatively low, the fish will lose their appetite and become more susceptible to disease, and if the air temperature is too high it will cause the fish to experience stress and fish gills can be permanent. broken. According to Budihadjo [16], the optimal $\mathrm{pH}$ value for wader fish cultivation ranges from 7-8. The $\mathrm{pH}$ fluctuation of pool water is more trusted by the weather. The effect of the presence or absence of rain has an important impact on changes in air $\mathrm{pH}$. According to Sucipto [20], dissolved oxygen (DO) which is good for freshwater cultivation is above $3 \mathrm{mg} / \mathrm{L}$. This is also related to the type of feed given because feed can affect the amount of ammonia but to increase air productivity, the dissolved oxygen content in the air should be kept at a level above $5 \mathrm{mg} / \mathrm{L}$, this is because at a level of $1 \mathrm{mg} / \mathrm{LL}$ it can cause growth in levels. slow and can cause stress in fish resulting in mass mortality of fish.

\section{COCLUSION}

Different feeding has no effect on the growth rate of wader fish.

\section{ACKNOWLEDGMENT}

I am grateful to the Department of Marine Affairs and Fisheries of Probolinggo Regency who has been willing to provide a loan for a tool to measure the quality of water in the waters during the research, as well as to the University of Muhammadiyah Malang analyst who has helped in testing the proximate feed used during the study.

\section{REFERENCES}

[1] Fathul, F., Liman N., Purwaningsih, dan Tantalo Y.S. 2014. Pengetahuan Pakan dan Formulasi Ransum [Skripsi]. Universitas Lampung. Bandar Lampung

[2] Adriyanto, S., Listyanto N. dan Rahmawati R. 2010. Pengaruh Pemberian Probiotik Dengan Dosis yang Berbeda terhadap Sintasan dan Pertumbuhan Benih Patin Jambal (Pangasius djambal). Forum Inovasi Teknologi Akuakultur 2010. 117-122 hal.

[3] Yanuar, V. 2017. Effect Of Different Types Of Feed On Growth Of Tilapia Fish (Oreochromis niloticus) and Water Qualiy In The Aquarium Maintenance. Journal Of Ziraa'ah. 42 (2): 91-99.

[4] Budiharjo, A. 2002. Seleksi dan Potensi Budidaya Jenis-Jenis Ikan Wader dari Genus Rasbora. Biodiversitas. 3 (2): 225-230

[5] Efendi M. 2002. Biologi Perikanan. Jakarta: Pustaka Nusantara.

[6] Ricker, W.E. 1975. Computation and Interpretation Of Biological Statistic Of Fish Population. Bull. Fish Res. Board.Can., 191-382

[7] Djajasewaka, H. 1985. Pakan Ikan. CV. Jakarta: Yasaguna. 45 hal

[8] Zairin, M. 2002. Sex Reversal Memproduksi Benih Ikan Jantan atau Betina. Jakarta: Penebar Swadaya

[9] Anggitasari, dan Septianti. 2016. Pengaruh Beberapa Jenis Pakan Komersil Terhadap Kinerja Produksi Kuantitatif dan Kualitatif Ayam Pedaging. Buletin Peternakan. 40 (3) : 187-196

[10] Hasim, Falah S, dan Dewi L. K. 2016. Effect of Boiled Cassava Leaves (Manihot esculenta Crantz) on Total Phenolic, Flavonoid and its Antioxidant Activity. Institut Pertanian Bogor. Bogor.

[11] Marzuqi, M. 2015. Pengaruh Kadar Karbohidrat Dalam Pakan Terhadap Pertumbuhan, Efisiensi Pakan, dan Aktivitas Enzim Amilase Pada Ikan Bandeng (Chanos chanos Frorsskal). Tesis. Program Studi Biologi. Universitas Udayana. Denpasar. ,

[12] Nasriani, A. R. N. dan Irdja, A. M. 2016. Pertumbuhan dan Kelangsungan Hidup Benih Ikan Nila (Oreochromis niloticus) Pada Pakan Buatan Yang Berbeda. [Skripsi], Program Studi Budidaya Perikanan. Universitas Muhammadiyah Gorontalo.

[13] Rachmawati, D. I. Samidjan. 2013. Efektivitas Substitusi Tepung Ikan Dengan Tepung Maggot Dalam Pakan Buatan Terhadap Pertumbuhan dan 
Kelulushidupan Ikan Patin (Pangasius pangasius). Jurnal Saintek Perikanan. Vol. 9, No 1.

[14] Nasrullah, F. A. 2019. Pengaruh Suhu Yang Berbeda Terhadap Pertumbuhan dan Kelangsungan Hidup Benih Ikan Bawal (Colossoma macropomum). [Skripsi]. Fakultas Perikanan dan Ilmu Kelautan. Universitas Pontianak.

[15] Kelabora, D.M. 2010. Pengaruh Suhu Tehadap Kelangsungan Hidup dan Pertumbuhan Larva Ikan Mas (Cyprinus carpio). Jurnal Berkala Perikanan Terubuk. 38(1) : 71-81

[16] Budiharjo, A. 2003. Pakan Tambahan Alternatif untuk Meningkatkan Pertumbuhan Ikan Wader. [Skripsi]. Universitas Sebelas Maret. Surakarta
[17] Barrow, P. A dan Hardy. 2001. Probiotic for Chickens. In: Probiotics the Scientific Basis. R. Filler (Ed). Chapman and Hall. London.

[18] Susanti, D. 2004. Pengaruh Penambahan Berbagai Silase Produk Perikanan dalam Ransum Pakan terhadap Pertumbuhan dan Kelulushidupan Benih Ikan Nila Gift. [Skripsi]. Universitas Diponegoro, 19 hlm

[19] Handajani, H. dan W. Widodo. 2010. Nutrisi Ikan. UMM Press, Malang, $271 \mathrm{hlm}$.

[20] Sucipto. 2004. Broadstock Management Ikan Mas dan Nila. Departemen Kelautan dan Perikanan, Jawa Barat : BBAT Sukabumi 